\title{
Stereoregularity of Poly(vinyl ether)s with a Narrow Molecular Weight Distribution Obtained by the Living Cationic Polymerization
}

\author{
Sadahito Aoshima, Yuuichi Ito, and Eiichi Kobayashi* \\ Department of Industrial Chemistry, Faculty of Science and Technology, \\ Science University of Tokyo, Noda, Chiba 278, Japan
}

(Received March 30, 1993)

\begin{abstract}
The stereoregularity of poly(isobutyl vinyl ether) with a narrow molecular weight distribution obtained by the living cationic polymerization in toluene at $+40 \sim-78^{\circ} \mathrm{C}$ was studied. As an initiating system, 1-(isobutoxy)ethyl acetate $/ \mathrm{EtAlCl}_{2}$ was used in the presence of methyl acetate or methyl pivalate as an added base, which can stabilize the propagating carbocation by the nucleophilic interaction. The stereostructure was determined as a diad fraction by ${ }^{13} \mathrm{C} \mathrm{NMR}$ spectroscopy and compared with that of the non-living polymer obtained in the absence of added bases. The diad fraction and the temperature coefficient of $\ln \left(P_{m} / P_{r}\right)$ for the living polymerization were equal to those for the non-living polymerization. The $\Delta H_{m}^{\ddagger}-\Delta H_{r}^{\ddagger}$ was determined to be $-900 \mathrm{cal} \mathrm{mol}^{-1}$, indicating that meso-rich poly(isobutyl vinyl ether) was synthesized favorably at low temperature polymerization. A counteranion and an added base in the living cationic polymerization of IBVE did not affect obviously the stereostructure of polymers obtained. The stereoregularity of seven living poly(vinyl ethers) having various side groups was investigated. Benzyl vinyl ether (meso: 89\%) and 2-benzoyloxyethyl vinyl ether (meso: 75\%) gave meso-rich living polymers in the presence of ethyl acetate as an added base at $0^{\circ} \mathrm{C}$. On the other hand, the stereostructure of living poly(2-benzoyloxyethyl vinyl ether) obtained in the absence of added bases (meso: $58 \%$ ) was quite different from that for the living polymerization in the presence of ethyl acetate. The $\ln \left(P_{m} / P_{r}\right)$ vs. $1 / T$ curve had a maximum at about $+20^{\circ} \mathrm{C}$, and it decreased with decreasing the polymerization temperature and became constant at the lower temperature below $0^{\circ} \mathrm{C}$. The facts and the profile about polymerization rates suggested a stabilization of the propagating carbocation by the side ester group of the terminal unit through an intramolecular interaction.

KEY WORDS Stereoregularity / Living Cationic Polymerization / Added Base / Stabilization of Carbocation / Side Ester Group / Vinyl Ethers / Benzyl Vinyl Ether / 2-Benzoyloxyethyl Vinyl Ether / Meso-Rich Polymer / Polymerization Mechanism /
\end{abstract}

Living polymerization has been known to be very useful and versatile for the control of the terminal functional groups, the polymer molecular weight, and its distribution (MWD). These control has been achieved by various polymerization systems; for example, living anionic polymerization, ${ }^{1}$ living cationic polymerization with $\mathrm{HI} / \mathrm{I}_{2}$ initiating system, ${ }^{2,3}$ group transfer polymerization, ${ }^{4}$ immortal polymerization, ${ }^{5}$ etc. On the other hand, the control of the stereostructure is also an important research, because physical and chemical properties of polymers $\left(T_{\mathrm{g}},{ }^{6}\right.$ solubility, ${ }^{7}$ reactivity, ${ }^{8}$ etc.) markedly depend on the stereostructure of the polymers. Recently, living stereospecific polymerization has been investigated mainly in the field of anionic and coordination polymerizations as follows: iso-

\footnotetext{
* To whom all correspondence should be addressed.
} 
tactic $^{9}$ or syndiotactic living poly(methyl methacrylate), ${ }^{10}$ isotactic living poly(vinyl pyridine)s, ${ }^{11}$ syndiotactic living poly( $\alpha$-olefine)s, ${ }^{12}$ etc.

The authors have recently reported on a new polymerization method for vinyl ether monomers that gives nearly monodisperse living polymers with controlled molecular weight, ${ }^{13}$ except for a study with the stereostructure. In this paper, to examine the stereostructure of living poly(vinyl ether)s, the living polymerization of isobutyl vinyl ether (IBVE) with Et $\mathrm{AlCl}_{2}$ in the presence of added bases was carried out under various conditions, and the results were compared with those of non-living polymers. The stereostructure of the living polymers obtained may be concerned with an ether group in the vinyl ether monomers, structures of added bases, counteranions, and polymerization temperatures, because the living polymer end can be expressed as Scheme 1. Thus, the authors investigated factors cotrolling the stereostructure of the living poly(vinyl ether)s in detail. In addition, following seven vinyl ethers (Scheme 2) having various side groups (alkyl, ether, ${ }^{14}$ and ester groups ${ }^{15}$ ) were polymerized in the presence of added base or in the absence of added base for $\mathrm{BzOVE}^{15}$ to give the living polymers with a narrow MWD, and the stereostructure was

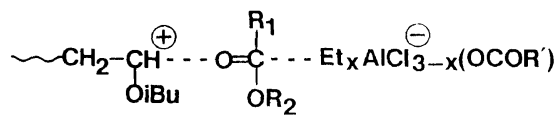

Scheme 1.

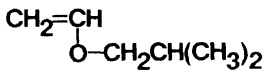

IBVE

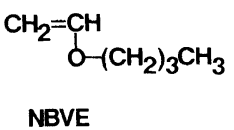

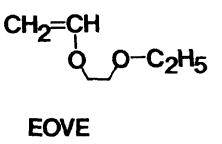

EOVE

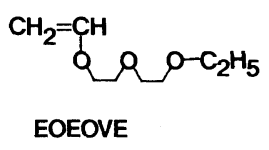

Scheme 2.
$\mathrm{CH}_{2}=\underset{\mathrm{O}}{\mathrm{C}-\mathrm{CH}_{2} \mathrm{C}\left(\mathrm{CH}_{3}\right)_{3}}$

NeoPVE

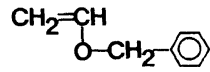

BnVE

determined. For instance, poly(BnVE) of meso $89 \%$ obtained at $0^{\circ} \mathrm{C}$ could be used for the preparation of isotactic poly(vinyl alcohol) with a narrow MWD. ${ }^{16}$ The meso content of living poly(BzOVE) obtained in the absence of added bases had a maximum value at about $+20^{\circ} \mathrm{C}$, suggesting an interaction between the living polymer end carbocation and the side ester group of the terminal unit.

\section{EXPERIMENTAL}

\section{Materials}

Commercial isobutyl vinyl ether (IBVE), $n$ butyl vinyl ether (NBVE), and neopentyl vinyl ether (NeoPVE)(Tokyo Kasei) were washed with an aqueous alkaline solution and then water, and distilled twice over calcium hydride. 2-Benzoyloxyethyl vinyl ether (BzOVE) was prepared by the $\mathrm{Bu}_{4} \mathrm{NI}$-catalyzed substitution reaction of 2-chloroethyl vinyl ether (Nisso Maruzen Chemical) with sodium benzoate at a reflux temperature for $12 \mathrm{~h}$, and distilled twice over calcium hydride ${ }^{15}$ (yield $51 \%$; bp $107-108^{\circ} \mathrm{C} / 2 \mathrm{mmHg}$ ) (lit. ${ }^{17} 157^{\circ} \mathrm{C} / 3 \mathrm{mmHg}$ ). Benzyl vinyl ether (BnVE) was prepared by the $\mathrm{Hg}\left(\mathrm{OCOCH}_{3}\right)_{2}$-catalyzed transetherification between ethyl vinyl ether (Tokyo Kasei) and benzyl alcohol (Wako Chemical) in the presence of molecular sieves $4 \mathrm{~A}$ at room temperature for $5 \mathrm{~h}$. The crude product was distilled under reduced pressure over sodium hydride and then over lithium aluminum hydride $^{16}$ (yield $38 \%$; bp $69.0^{\circ} \mathrm{C} / 10 \mathrm{mmHg}$ ) (lit. ${ }^{18} 69.0^{\circ} \mathrm{C} / 10 \mathrm{mmHg}$ ). 2-Ethoxyethyl vinyl

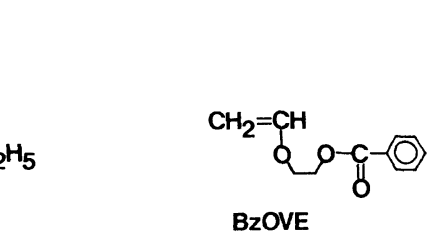


ether (EOVE) and 2-(2-ethoxy)ethoxyethyl vinyl ether (EOEOVE) were synthesized by the $\mathrm{Bu}_{4} \mathrm{NI}$-catalyzed substitution reaction of 2chloroethyl vinyl ether with the corresponding sodium alkoxides at a reflux temperature for $12 \mathrm{~h},{ }^{19}$ and distilled twice over calcium hydride $^{14}$ [each yield $\sim 40 \%$; bp $126^{\circ} \mathrm{C}$ for EOVE (lit. ${ }^{19} 126^{\circ} \mathrm{C}$ ), $189^{\circ} \mathrm{C}$ for EOEOVE (lit. $\left.\left.{ }^{14} 189^{\circ} \mathrm{C}\right)\right]$.

$\mathrm{EtAlCl}_{2}$ and $\mathrm{Et}_{2} \mathrm{AlCl}$ (Nippon Aluminum Alkyls) were distilled under reduced pressure. $\mathrm{Et}_{1.5} \mathrm{AlCl}_{1.5}$ was prepared by reaction of $\mathrm{EtAlCl}{ }_{2}$ with an equimolar amount of $\mathrm{Et}_{2} \mathrm{AlCl}$ at room temperature for $8 \mathrm{~h}$, and the crude product was fractionally distilled at $95^{\circ} \mathrm{C} / 14$ mmHg. ${ }^{14}$ As a solvent or an added base, toluene, hexane, ethyl acetate, methyl acetate, methyl pivalate, isopropyl acetate, methyl chloroacetate, and tetrahydrofuran (THF) (Tokyo Kasei) were distilled twice over calcium hydride or metallic sodium for THF just before use. 1-(Isobutoxy)ethyl acetate (1), 1-(isobutoxy)ethyl pivalate, and 1-(isobutoxy)ethyl $t$-butylacetate as a cationogen were prepared from IBVE and the corresponding carboxylic acids, ${ }^{13}$ and distilled over calcium hydride under reduced pressure. 1-(Isobutoxy)ethyl trifluoroacetate was synthesized in situ from IBVE and trifluoroacetic acid in 1:1 molar ratio in hexane, and the quantitative formation was confirmed by ${ }^{1} \mathrm{H}$ NMR spectroscopy. ${ }^{13,20}$

\section{Polymerization}

The polymerization was carried out at $+70 \sim-78^{\circ} \mathrm{C}$ under a dry nitrogen atmosphere in a glass tube baked at $250^{\circ} \mathrm{C}$ equipped with a three-way stopcock. ${ }^{13}$ The reaction was initiated by addition of $\mathrm{EtAlCl}_{2}, \mathrm{Et}_{2} \mathrm{AlCl}$, or $\mathrm{Et}_{1.5} \mathrm{AlCl}_{1.5}$ solution in hexane into a mixture of monomer, added base, and cationogen in toluene or hexane at the polymerization temperature by a medical syringe. After a proper interval, the polymerization was quenched with $0.3 \mathrm{wt} \%$ ammoniac methanol. The quenched reaction mixture was sequentially washed with dilute hydrochloric acid $(0.6 \mathrm{M})$ and with water to remove the initiator residues, and then neutralized with a dilute aqueous sodium hydroxide $(0.5 \mathrm{M})$. In the cases of EOVE and EOEOVE, the quenched reaction mixtures were diluted with dichloromethane, ${ }^{14}$ and then were treated in a similar manner as above. The product polymer was recovered from the organic layer by evaporation of the solvent and the remaining monomer under reduced pressure and vacuum dried overnight. The conversion of the monomer was measured by gravimetry.

\section{Measurement}

The MWDs of the polymers were measured using size exclusion chromatography (SEC) in chloroform at $40^{\circ} \mathrm{C}$ with a CCPD instrument (TOSOH) equipped with three polystyrene gel columns (TSK gel G-2000, 3000, and 4000; $8.0 \mathrm{~mm}$ (i.d.) $\times 300 \mathrm{~mm}$ each) and a refractive index detector. The number-average molecular weight $\left(\bar{M}_{n}\right)$ and $\bar{M}_{w} \bar{M}_{n}$ were calculated for SEC curves on the basis of the polystyrene calibration.

${ }^{13} \mathrm{C}$ NMR spectra of the polymer samples except for poly $(\mathrm{BnVE})$ were recorded at $27^{\circ} \mathrm{C}$ in $\mathrm{CDCl}_{3}(\geq 10 \mathrm{wt} \%)$ using a JEOL FX90Q spectrometer pulsed Fourier transform system operating at $22.49 \mathrm{MHz}$. Instrument conditions were $\pi / 4$ pulse of $11 \mu \mathrm{s}, 2.0 \mathrm{~s}$ repetition time, and $4500 \mathrm{~Hz}$ sweep width. The number of accumulation was over $10^{4}$. The ratios of $\operatorname{meso}(m)$ to $\operatorname{racemo}(r)$ in the diad were determined from methylene area of the main chain in the ${ }^{13} \mathrm{C}$ NMR spectra. ${ }^{21}$ The diad fraction of poly(BnVE) was calculated from the triad fraction determined from the signals of methylene proton in the side chain observed at $90 \mathrm{MHz}{ }^{1} \mathrm{H}$ NMR spectroscopy at $27^{\circ} \mathrm{C}$ in $\mathrm{CDCl}_{3} \cdot{ }^{18}$

\section{RESULTS AND DISCUSSION}

\section{Stereoregularity of the Living and Non-Living Poly (IBVE)}

The stereoregularity of the living poly(IBVE) 


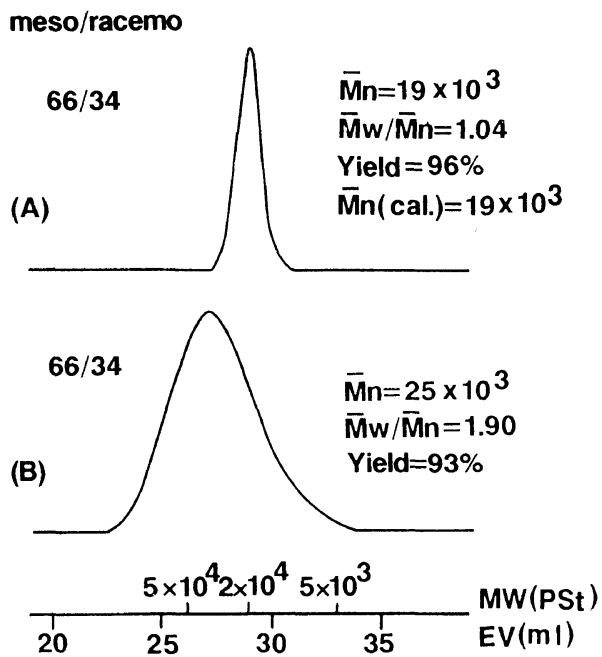

Figure 1. MWDs and tacticity of poly(IBVE) obtained with $1 / \mathrm{EtAlCl}_{2}$ in the presence of $(\mathrm{A})$ or in the absence of (B) methyl acetate in toluene at $+40^{\circ} \mathrm{C}$ : $[\mathrm{IBVE}]_{0}=0.76 \mathrm{M}$, $[1]_{0}=\left[\mathrm{EtAlCl}_{2}\right]_{0}=4 \mathrm{mM},[$ methyl acetate $]=1.0 \mathrm{M}$.

was determined by ${ }^{13} \mathrm{C}$ NMR spectroscopy and compared with that of the non-living one. Living cationic polymerization of IBVE was achieved with $1 / \mathrm{EtAlCl}_{2}$ in the presence of methyl acetate in toluene at $+40^{\circ} \mathrm{C}$, to give the polymer with a narrow MWD $\left(\bar{M}_{w} / \bar{M}_{n}=\right.$ 1.04 , at $96 \%$ conv.) as shown in Figure 1. Non-living polymer with a broad MWD $\left(\bar{M}_{w} / \bar{M}_{n}=1.90\right.$, at $93 \%$ conv.) was obtained in the absence of the added base. The stereoregularity of the living polymer was found to be meso-rich $($ meso/racemo $=66 / 34)$, and the diad fraction was equal to that of the non-living polymer.

To obtain further information on the stereoregularity of each polymer, the dependence on the polymerization temperature was investigated. The polymerization of IBVE was carried out at $+40 \sim-78^{\circ} \mathrm{C}$ with $\mathbf{1} / \mathrm{EtAlCl}_{2}$ as an initiating system in toluene in the presence of methyl pivalate. Methyl pivalate used as an added base is suitable for a faster living polymerization of IBVE than methyl acetate, ${ }^{22}$ especially at low temperatures. As shown in Figure 2, the diad fraction was plotted against $1 / T$ by the following

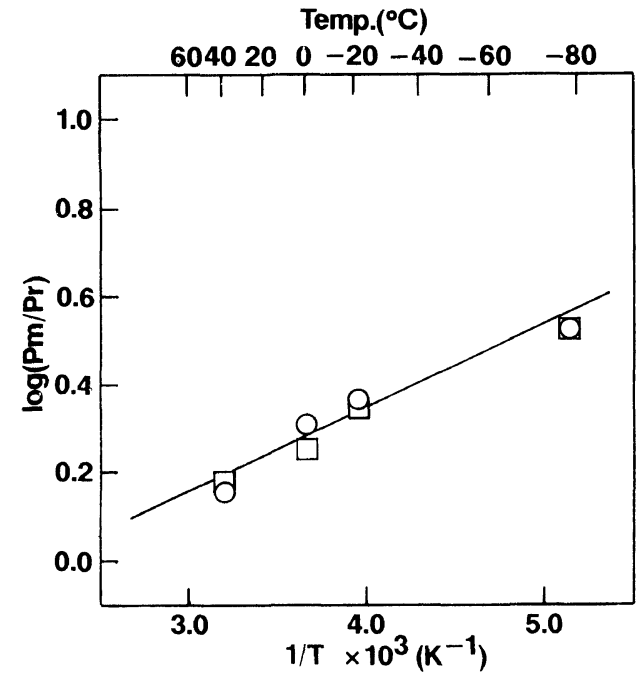

Figure 2. Relationships between polymerization temperature and tacticity of poly(IBVE) obtained with $\mathbf{1}$ $\mathrm{EtAlCl}_{2}$ in the presence of $(\mathrm{O})$ or in the absence of $(\square)$ methyl pivalate in toluene at $+40 \sim-78^{\circ} \mathrm{C}$, yield $>90 \%$ : $[\mathrm{IBVE}]_{0}=0.76 \mathrm{M},[1]_{0} /\left[\mathrm{EtAlCl}_{2}\right]_{0}=4 \mathrm{mM} / 20 \mathrm{mM},[\mathrm{me}-$ thyl pivalate $]=1.0 \mathrm{M}$.

equation $^{23}$ :

$$
\begin{aligned}
\ln \left(P_{m} / P_{r}\right)= & \left(\Delta S_{m}^{\neq}-\Delta S_{r}^{\ddagger}\right) / R \\
& -\left(\Delta H_{m}^{\neq}-\Delta H_{r}^{\ddagger}\right) / R T
\end{aligned}
$$

where $P_{m}$ and $P_{r}$ are the parameter of the meso and racemo placements, respectively. The values of $\ln \left(P_{m} / P_{r}\right)$ of the polymers obtained in the living and non-living systems were almost equal at each temperature, and increased with a decrease in the polymerization temperature. The increase was a general tendency for the cationic polymerization of vinyl ethers in non-polar solvents. The value of $\Delta H_{m}^{\neq}-\Delta H_{r}^{\neq}$ and that of $\Delta S_{m}^{\neq}-\Delta S_{r}^{\neq}$at $+40^{\circ} \mathrm{C}$ were found to be $-900 \mathrm{cal} \mathrm{mol}^{-1}$ and $-1000 \mathrm{cal} \mathrm{mol}^{-1}$, respectively. These results indicate that the living and the non-living polymerizations of IBVE exhibit not only the same stereoregularity but also the same temperature dependence of the tacticity. That is, although the counteranion was generally known to influence such stereoregulation, the basic additive used here does not affect the stereoregulation but induces mainly living 
nature of the growing polymer carbocation by suppressing unfavorable chain transfer and termination reactions.

\section{Effect of Added Base and Counteranion on the} Stereostructure of the Living Poly(IBVE)

Since the living polymer end carbocation was expressed as Scheme 1, the stereostructure of the penultimate unit is thought to be controlled by relative arrangement of the living polymer end, added base, counteranion, and coming IBVE. To elucidate the effect of the structure of added bases, the authors herein employed methyl acetate, methyl pivalate, isopropyl acetate, and methyl chloroacetate as a basic additive in the polymerization of IBVE with $1 / \mathrm{EtAlCl}_{2}$ in toluene at $0^{\circ} \mathrm{C}$. In any cases, the meso $\%$ unchanged in the range of $62 \sim 66 \%$

Table I. Effect of added base on the stereoregularity of living poly(IBVE) ${ }^{a}$

\begin{tabular}{|c|c|c|c|}
\hline Added base & $\bar{M}_{n} \times 10^{-3}$ & $\bar{M}_{w} / \bar{M}_{n}$ & meso/racemo \\
\hline $\mathrm{CH}_{3} \mathrm{COOCH}_{3}$ & 19 & 1.04 & $66 / 34$ \\
\hline$\left(\mathrm{CH}_{3}\right)_{3} \mathrm{CCOOCH}_{3}$ & 20 & 1.07 & $65 / 35$ \\
\hline $\mathrm{CH}_{3} \mathrm{COOCH}\left(\mathrm{CH}_{3}\right)_{2}$ & 22 & 1.08 & $62 / 38$ \\
\hline $\mathrm{ClCH}_{2} \mathrm{COOCH}_{3}$ & 19 & 1.20 & $64 / 36$ \\
\hline
\end{tabular}

a Polymerization conditions: $[\mathrm{IBVE}]_{0}=0.76 \mathrm{M},[\mathrm{I}]_{0}=$ $\left[\mathrm{EtAlCl}_{2}\right]_{0}=4 \mathrm{mM}$, [added base $]=1.0 \mathrm{M}$, in toluene at $+40^{\circ} \mathrm{C}$; yield, $>90 \% ; \bar{M}_{n}$ (cal.) $=19 \times 10^{3}$ as shown in Table I, indicating that the effect of the steric hindrance $\left(R_{1}\right.$ and $R_{2}$ in Scheme 1) and nucleophilicity of added bases was unexpectedly small.

The effect of the counteranions was also investigated by using the combination of four initiators containing various aliphatic acid residues $\left(-\mathrm{OCOCH}_{3},-\mathrm{OCOC}\left(\mathrm{CH}_{3}\right)_{3},-\mathrm{OCOCH}_{2}-\right.$ $\mathrm{C}\left(\mathrm{CH}_{3}\right)_{3}$, and $\left.-\mathrm{OCOCF}_{3}\right)$ and three alkylaluminum halides $\left(\mathrm{EtAlCl}_{2}, \mathrm{Et}_{1.5} \mathrm{AlCl}_{1.5}\right.$, and $\left.\mathrm{Et}_{2} \mathrm{AlCl}\right)$. It can be seen from Table II that there is no remarkable change in meso \%, and various types of acid residues or alkylaluminum halides had little influence on the stereoregularity of the polymers. Further inspection of Table II shows that the initiator $\left[\mathrm{CH}_{3} \mathrm{CH}-\right.$ $\left.(\mathrm{OiBu}) \mathrm{OCOC}\left(\mathrm{CH}_{3}\right)_{3}\right]$ having a more bulky acid residue near the carbonyl group than 1 gives somewhat meso-rich polymer (meso: $73 \%$ ), while the initiator having an electronwithdrawing group $\left[\mathrm{CH}_{3} \mathrm{CH}(\mathrm{OiBu}) \mathrm{OCOCF}_{3}\right]$ gives somewhat less meso polymer (meso: $65 \%$ ) than that obtained by initiator 1 .

\section{Stereoregularity of Various Living Poly(vinyl ethers)}

The authors have recently succeeded in the living cationic polymerization of various vinyl ethers, for example, alkyl vinyl ethers of a variety of the steric crowding (IBVE, NBVE, ${ }^{24}$

Table II. Effect of counteranion on the stereoregularity of living poly(IBVE) ${ }^{\mathrm{a}}$

\begin{tabular}{llccc}
\hline $\begin{array}{l}\mathrm{R}^{\prime} \text { of OCOR' } \\
\text { group }\end{array}$ & $/ \mathrm{Et}_{x} \mathrm{AlCl}_{3-x}$ & $\bar{M}_{n} \times 10^{-3}$ & $\bar{M}_{w} / \bar{M}_{n}$ & meso/racemo \\
\hline $\mathrm{CH}_{3-}$ & $/ \mathrm{EtAlCl}_{2}$ & 20 & 1.20 & $69 / 31$ \\
$\left(\mathrm{CH}_{3}\right)_{3} \mathrm{C}-$ & $/ \mathrm{EtAlCl}_{2}$ & 19 & 1.18 & $73 / 27$ \\
$\left(\mathrm{CH}_{3}\right)_{3} \mathrm{CCH}_{2-}$ & $/ \mathrm{EtAlCl}_{2}$ & 19 & 1.19 & $66 / 34$ \\
$\mathrm{CF}_{3-}$ & $/ \mathrm{EtAlCl}_{2}$ & 19 & 1.19 & $65 / 35$ \\
\hline $\mathrm{CH}_{3-}$ & $/ \mathrm{EtAlCl}_{2}$ & 20 & 1.20 & $69 / 31$ \\
$\mathrm{CH}_{3-}$ & $/ \mathrm{Et}_{1.5} \mathrm{AlCl}{ }_{1.5}$ & 20 & 1.06 & $70 / 30$ \\
$\mathrm{CH}_{3-}$ & $/ \mathrm{Et}_{2} \mathrm{AlCl}$ & 23 & 1.08 & $70 / 30$ \\
\hline
\end{tabular}

Polymerization conditions: $[\mathrm{IBVE}]_{0}=0.76 \mathrm{M}, \quad\left[\mathrm{CH}_{3} \mathrm{CH}(\mathrm{OiBu}) \mathrm{OCOR}^{\prime}\right]_{0}=\left[\mathrm{Et}_{x} \mathrm{AlCl}_{3-x}\right]_{0}=4 \mathrm{mM}, \quad\left[\mathrm{ClCH}_{2}-\right.$ $\left.\mathrm{COOCH}_{3}\right]=1.0 \mathrm{M}$, in toluene at $-20^{\circ} \mathrm{C} ;$ yield, $>90 \% ; \bar{M}_{n}$ (cal.) $=19 \times 10^{3}$.

a Fragment of cationogen $\mathrm{CH}_{3}-\mathrm{CH}-\mathrm{O}-\mathrm{CO}-\mathrm{R}^{\prime}$. $\mathrm{OiBu}$ 
Table IIII. Tacticity of living poly(vinyl ethers)

\begin{tabular}{llccc}
\hline Monomer & Added base & $\bar{M}_{n} \times 10^{-3}$ & $\bar{M}_{w} / \bar{M}_{n}$ & meso/racemo \\
\hline IBVE $^{\mathrm{a}}$ & $\mathrm{CH}_{3} \mathrm{COOC}_{2} \mathrm{H}_{5}$ & 19 & 1.05 & $70 / 30$ \\
$\mathrm{NBVE}^{\mathrm{b}}$ & $\mathrm{CH}_{3} \mathrm{COOCH}_{3}$ & 20 & 1.04 & $70 / 30$ \\
$\mathrm{NeOPVE}^{\mathrm{b}}$ & $\mathrm{CH}_{3} \mathrm{COOCH}_{3}$ & 18 & 1.03 & $66 / 34$ \\
$\mathrm{BnVE}^{\mathrm{a}}$ & $\mathrm{CH}_{3} \mathrm{COOC}_{2} \mathrm{H}_{5}$ & 20 & 1.06 & $89 / 11$ \\
EOVE $^{\mathrm{a}, \mathrm{c}}$ & $\mathrm{THF}(0.2 \mathrm{M})$ & 20 & 1.10 & $62 / 38$ \\
EOEOVE $^{\mathrm{a}, \mathrm{c}}$ & $\mathrm{THF}(0.2 \mathrm{M})$ & 16 & 1.10 & $61 / 39$ \\
BzOVE $^{\mathrm{a}}$ & $\mathrm{CH}$ & 15 & 1.10 & $75 / 25$ \\
& $\mathrm{None}$ & 15 & 1.09 & $58 / 42$ \\
\hline
\end{tabular}

Polymerization conditions: $[\text { monomer }]_{0}=10 \mathrm{vol} \%,[1]_{0} /\left[\mathrm{EtAlCl}_{2}\right]_{0}=4 \mathrm{mM} / 20 \mathrm{mM},[$ added base $]=1.0 \mathrm{M}$, at $0{ }^{\circ} \mathrm{C}$; yield $>90 \%$.

${ }^{a}$ In toluene or ${ }^{b}$ in hexane.

c $[1]_{0} /\left[\mathrm{Et}_{1.5} \mathrm{AlCl}_{1.5}\right]_{0}=4 \mathrm{mM} / 20 \mathrm{mM}$.

NeoPVE,$^{24}$ and $\left.B n V E E^{16}\right)$, vinyl ethers having oxyethylene groups ${ }^{14}$ (EOVE and EOEOVE) and a vinyl ether having an ester group ${ }^{15}$ (BzOVE). Table III summarized the stereoregularity of the living polymers obtained in the presence of added bases at $0^{\circ} \mathrm{C}$. Since these monomers have various reactivity, the most suitable initiating system and added base were used, respectively. (It was already confirmed in the previous section that such minor differences of conditions hardly affected the stereostrcutre of the polymer obtained.) The meso diad fractions of polymers having the aliphatic alkyl group were about $70 \%$, but that of the polymer having benzyl group [poly(BnVE)] was $89 \%$. The meso regulation of the polymers having benzoyloxy ester group [poly(BzOVE)] and ether groups [poly(EOVE) and poly(EOEOVE)] were $75 \%$ and $61-62 \%$, respectively.

The effect of the monomer structure and the polymerization temperature on the tacticity of poly(IBVE), poly(BnVE), poly(EOEOVE), and poly(BzOVE) was investigated at $+60 \sim$ $-20^{\circ} \mathrm{C}$ in detail. Poly(BnVE) had a slightly large temperature coefficient in comparison with poly(IBVE), poly(BzOVE), and poly(EOEOVE) (Figure 3). The $\Delta H_{m}^{\ddagger}-\Delta H_{r}^{\ddagger}$ and $\Delta S_{m}^{\ddagger}-\Delta S_{r}^{\ddagger}$ for the diad fraction determined by eq 1 are listed in Table IV. The $\Delta H_{m}^{\neq}$for meso diad was smaller than $\Delta H_{r}^{\ddagger}$ for racemo

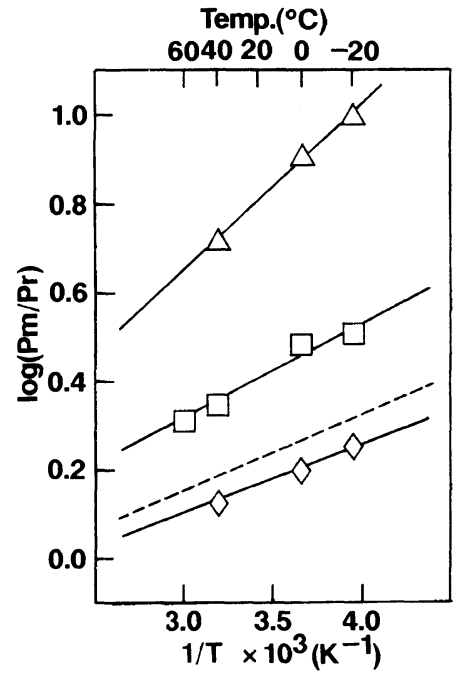

Figure 3. Relationships between polymerization temperature and tacticity of poly(IBVE)(bloken line taken from Figure 2), poly $(\mathrm{BnVE})(\triangle)$, poly(BzOVE)( $\square)$ obtained with $1 / \mathrm{EtAlCl}_{2}$ in the presence of ethyl acetate in toluene at $+60 \sim-20^{\circ} \mathrm{C}$, yield $>90 \%$ : $[\text { monomer }]_{0}=10$ $\operatorname{vol} \%,[1]_{0} /\left[\mathrm{EtAlCl}_{2}\right]_{0}=4 \mathrm{mM} / 20 \mathrm{mM}$, [ethyl acetate] = $1.0 \mathrm{M}$; poly(EOEOVE) $(\diamond)$ obtained with $1 / \mathrm{Et}_{1.5} \mathrm{AlCl}_{1.5}$ in the presence of THF in toluene at $+40 \sim-20^{\circ} \mathrm{C}$, yield $>90 \%$ : $[\mathrm{EOEOVE}]_{0}=10 \mathrm{vol} \%,[1]_{0} /\left[\mathrm{Et}_{1.5} \mathrm{AlCl}_{1.5}\right]_{0}=4$ $\mathrm{mM} / 20 \mathrm{mM},[\mathrm{THF}]=0.2 \mathrm{M}$.

diad, that is, the living cationic polymerization of all vinyl ethers employed here gives favorably meso-rich polymers at a low polymerization temperature. The values of $\Delta H_{m}^{\ddagger}-\Delta H_{r}^{\ddagger}$ show that $\mathrm{BnVE}$ is the most favorable monomer to synthesize the meso-rich 
Table IV. $\Delta H_{m}^{\neq}-\Delta H_{r}^{\neq}$and $\Delta S_{m}^{\ddagger}-\Delta S_{r}^{\ddagger}$ values for diad fraction

\begin{tabular}{lccc}
\hline Monomer & (Added base) & $\begin{array}{c}\Delta H_{m}^{\ddagger}-\Delta H_{r}^{\ddagger} / \\
\mathrm{cal} \mathrm{mol}^{-1}\end{array}$ & $\begin{array}{c}\Delta S_{m}^{\ddagger}-\Delta S_{r}^{\ddagger} / \\
\mathrm{cal} \mathrm{mol}^{-1} \\
\text { at }+40^{\circ} \mathrm{C}\end{array}$ \\
\hline IBVE & $\left(\mathrm{CH}_{3} \mathrm{COOC}_{2} \mathrm{H}_{5}\right)$ & -900 & -1000 \\
BnVE & $\left(\mathrm{CH}_{3} \mathrm{COOC}_{2} \mathrm{H}_{5}\right)$ & -1700 & -700 \\
EOEOVE & $\left(\mathrm{THF}^{\mathrm{a}}\right)$ & -800 & -600 \\
BzOVE & $\left(\mathrm{CH}_{3} \mathrm{COOC}_{2} \mathrm{H}_{5}\right)$ & -1000 & -400 \\
\hline
\end{tabular}

Polymerization conditions: $[\text { monomer }]_{0}=10 \mathrm{vol} \%,[1]_{0} /$ $\left[\mathrm{EtAlCl}_{2}\right]_{0}=4 \mathrm{mM} / 20 \mathrm{mM}$, [added base] $=1.0 \mathrm{M}$, in toluene at $+60 \sim-20^{\circ} \mathrm{C}$; yield $>90 \%$.

a $[1]_{0} /\left[\mathrm{Et}_{1.5} \mathrm{AlCl}_{1.5}\right]_{0}=4 \mathrm{mM} / 20 \mathrm{mM},[\mathrm{THF}]=0.2 \mathrm{M}$.

polymer. The side group of the growing BnVE unit may prefer the favorable conformation of the intermediate carbocation to induce one side attack of the monomer. On the other hand, the difference between $\Delta S_{m}^{\neq}$and $\Delta S_{r}^{\neq}$was a little smaller.

Stereostructure of Poly(BzOVE) and the Polymerization Mechanism

Recently, the living cationic polymerization of $\mathrm{BzOVE}$ with $1 / \mathrm{EtAlCl}_{2}$ in the absence of added bases was also succeeded. ${ }^{25}$ Furthermore, four $p$-substituted $\mathrm{BzOVE}$ derivatives $\left(p-\mathrm{X}-\mathrm{C}_{6} \mathrm{H}_{4} \mathrm{COOC}_{2} \mathrm{H}_{4} \mathrm{OCH}=\mathrm{CH}_{2}: \quad \mathrm{X}=\right.$ $\mathrm{CH}_{3} \mathrm{O}, \mathrm{CH}_{3}, \mathrm{H}, \mathrm{Cl}$ ) were polymerized without added bases. ${ }^{15}$ In any cases, living polymers with a narrow MWD were obtained, whereas the polymerization rates depended on its $p$-substituted groups as follows: $\mathrm{CH}_{3} \mathrm{O}<\mathrm{CH}_{3}$ $<\mathrm{H}<\mathrm{Cl}$. On the basis of the results, it was suggested that the propagating carbocations were stabilized not only by the externally added bases but also by the pendant ester group of the terminal unit. However, the detailed stabilization mechanism was not discussed yet.

The stereoregularity of polymers is known to be correlated to the polymerization mechanism, and gives the significant information regarding the nature of propagating species (the degree of dissociation, the coordination state, etc.). ${ }^{26}$ To obtain such information, the stereoregularity of poly-

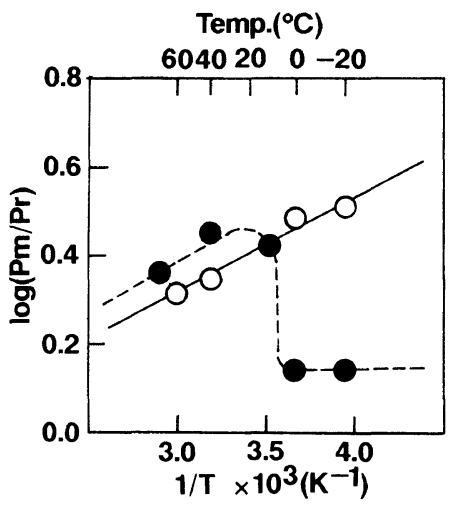

Figure 4. Relationships between polymerization temperature and tacticity of poly(BzOVE) obtained with $\mathbf{1} /$ EtAlCl${ }_{2}$ in the presence $(\mathrm{O})$ or in the absence of ethyl acetate $(\bigcirc)$ in toluene at $+70 \sim-20^{\circ} \mathrm{C}$, yield $>90 \%$ : $[\mathrm{BzOVE}]_{0}=0.56 \mathrm{M},[1]_{0} /\left[\mathrm{EtAlCl}_{2}\right]_{0}=4 \mathrm{mM} / 20 \mathrm{mM}$, [ethyl acetate] $=1.0 \mathrm{M}$.
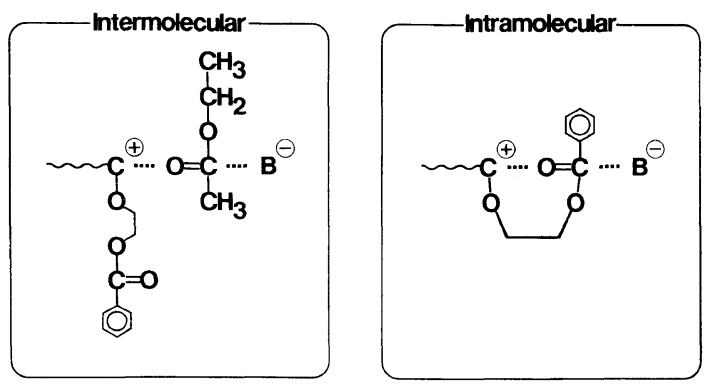

Scheme 3.

(BzOVE) obtained at $+70 \sim-20^{\circ} \mathrm{C}$ in the absence of added bases was determined as shown in Figure 4. In the range of +70 to about $+20^{\circ} \mathrm{C}$, the temperature coefficient was almost identical with that in the presence of ethyl acetate. On the other hand, at the temperature below $+20^{\circ} \mathrm{C}, \ln \left(P_{m} / P_{r}\right)$ decreased steeply and then gradually became constant. These characteristic features suggest the change of interaction mode of the carbocation and the pendant ester group of the terminal unit at the critical temperature $\left(\sim+20^{\circ} \mathrm{C}\right)$. That is, at lower temperatures, the growing carbocation was thought to be stabilized through the intramolecular interaction with the pendant ester group of the terminal unit as shown in Scheme 3. On that 
occasion, the side ester group interacted with the carbocation did not interfere the monomer insertion from each side to give nonstereoregular polymers. In contrast, at higher temperatures the carbocation may be stabilized by side ester groups of poly(BzOVE) and/or BzOVE monomer, since the intramolecular interaction between the carbocation and the pendant ester group of the terminal unit becomes difficult at such higher temperatures. Consequently, the temperature dependence of the steric structure of poly(BzOVE) (Figure 4) may be accounted for by assuming that, in the absence of an added base and at temperatures below $+20^{\circ} \mathrm{C}$, the growing end is in an intramolecular interaction with the terminal pendant ester group.

\section{REFERENCES}

1. M. Szwarc, Nature (London), 178, 1168 (1956).

2. M. Miyamoto, M. Sawamoto, and T. Higashimura, Macromolecules, 17, 265 (1984).

3. T. Higashimura, S. Aoshima, and M. Sawamoto, Makromol. Chem., Macromol. Symp., 3, 99 (1986).

4. D. Y. Sogah, W. R. Hertler, O. W. Webster, and G. M. Cohen, Macromolecules, 20, 1473 (1987).

5. S. Asano, T. Aida, and S. Inoue, J. Chem. Soc., Chem. Commun., 1148 (1985).

6. T. Kitayama, K. Ute, and K. Hatada, Br. Polym. J., 23, 5 (1990).

7. K. Hatada, T. Kitayama, Y. Okamoto, K. Ohta, Y. Umemura, and H. Yuki, Makromol. Chem., 179, 485 (1978).

8. B. Tamai and N. Goudargian, Polym. Bull., 23, 295
(1990).

9. K. Hatada, K. Ute, K. Tanaka, Y. Okamoto, and T. Kitayama, Polym. J., 18, 1037 (1986).

10. T. Kitayama, T. Shinozaki, T. Sakamoto, M. Yamamoto, and K. Hatada, Makromol. Chem., Suppl., 15, 167 (1989).

11. A. Soum and M. Fontanille, Makromol. Chem., 181, 799 (1980).

12. Y. Doi, S. Ueki, and T. Keii, Macromolecules, 12, 814 (1979).

13. S. Aoshima and T. Higashimura, Macromolecules, 22, 1009 (1989).

14. S. Aoshima, H. Oda, and E. Kobayashi, J. Polym. Sci., A, 30, 2407 (1992).

15. S. Aoshima, H. Kamae, and E. Kobayashi, Polym. Prepr. Jpn., 40, 243 (1991).

16. S. Aoshima, S. Iwasa, and E. Kobayashi, Polym. J., to be published.

17. O. N. Mikhant'eva, V. S. Romanova, and V. B. Mikhant'ev, Zh. Prinkl. Khim. (Lenigrad), 58, 1112 (1985); Chem. Abstr., 103, 178662a (1985).

18. H. Yuki, K. .Hatada, K. Ota, I. Kinoshita, S. Murahashi, K. Ono, and Y. Ito, J. Polym. Sci., A-1, 7, 1517 (1969)

19. H. J. Schneider, U. S. Patent 3,062,892 (1962); Chem. Abstr., 58, 10082 (1963).

20. S. Aoshima, Y. Ito, and E. Kobayashi, Polym. Prepr. Jpn., 40, 1713 (1991).

21. K. Hatada, T. Kitayama, N. Matsuo, and H. Yuki, Polym. J., 15, 719 (1983).

22. S. Aoshima, K. Shachi, E. Kobayashi, and T. Higashimura, Makromol. Chem., 192, 1749 (1991).

23. F. A. Bovey, J. Polym. Sci., 46, 59 (1960).

24. S. Aoshima, K. Shachi, and E. Kobayashi, Polym. $J$. , to be published.

25. S. Aoshima and T. Higashimura, Polym. Bull., 15, 417 (1986).

26. C. E. H. Bawn and A. Ledwith, Quart. Rev., 16, 361 (1962). 